\title{
INEQUALITIES OF THE JENSEN AND EDMUNDSON-LAH-RIBARIČ TYPE FOR 3-CONVEX FUNCTIONS WITH APPLICATIONS
}

\author{
RoZARIJA Mikić, Đilda PEČARIĆ AND Josip PEČARIĆ
}

Abstract. In this paper we derive some Jensen and Edmundson-Lah-Ribarič type inequalities for positive linear functionals and 3-convex functions. Obtained results are then applied to generalized means and power means, as well as to the generalized $f$-divergence functional. Examples with Zipf-Mandelbrot law are given.

Mathematics subject classification (2010): 26A16, 60E05, 60E15.

Keywords and phrases: Jensen inequality, Edmundson-Lah-Ribarič inequality, 3-convex functions, $f$ divergence, Zipf-Mandelbrot law.

\section{REFERENCES}

[1] S. Abramovich, Quasi-arithmetic means and subquadracity, J. Math. Inequal. 9, 4 (2015), 11571168.

[2] P. R. BeESACK AND J. E. PeČARIĆ, On the Jessen's inequality for convex functions, J. Math. Anal. Appl. 110, 2 (1985), 536-552.

[3] M. BEN BASSAT, $f$-entropies, probability of error, and feature selection, Inform. Contr. 39, 3 (1978), 227-242.

[4] P. S. Bullen, D. S. Mitrinović and P. M. Vasić, Means and their inequalities, D. Reidel Publishing Co., Dordrecht, Boston, Lancaster and Tokyo.

[5] C. H. Chen, Statistical Pattern Recognition, Hayden Book Co., Rochelle Park, NJ.

[6] D. ChOI, M. KRnić AND J. PEČARI Ć, Improved Jensen-type inequalities via linear interpolation and applications, J. Math. Inequal. 11, 2 (2017), 301-322.

[7] C. K. ChOw AND C. N. LiU, Approximating discrete probability distributions with dependence trees, IEEE Trans. Inform. Theory 14, 3 (1968), 462-467.

[8] I. CsiszáR, Information measures: A critical survey, Trans. 7th Prague Conf. on Info. Th. Statist. Decis. Funct., Random Processes and 8th European Meeting of Statist. B, (1978), 73-86.

[9] I. CSISZÁR, Information-type measures of difference of probability functions and indirect observations, Studia Sci. Math. Hungar. 2, (1967), 299-318.

[10] L. EgGhe And R. Rousseau, Introduction to Informetrics. Quantitative Methods in Library, Documentation and Information Science, Elsevier Science Publishers, New York.

[11] D. V. GoKhale And S. Kullback, Information in Contingency Tables, Marcel Dekker, New York.

[12] L. HonvÁth, Weighted form of a recent refinement of the discrete Jensen's inequality, Math. Inequal. Appl. 17, 3 (2014), 947-961.

[13] L. Horváth And J. PeČARIĆ, A refinement of the discrete Jensen's inequality, Math. Inequal. Appl. 14, 4 (2011), 777-791.

[14] S. IVELIĆ AND J. PEČARIĆ, Generalizations of converse Jensen's inequality and related results, J. Math. Inequal. 5, 1 (2011), 43-60.

[15] R. JAKŠIC, M. KRnIĆ AND J. PEČARIĆ, More precise estimates for the Jensen operator inequality obtained via the Lah-Ribarič inequality, Appl. Math. Comp. 249 (2014), 346-355.

[16] R. JAKŠIC AND J. PEČARIĆ, New converses of the Jessen and Lah-Ribarič inequalities II, J. Math. Inequal. 7, 4 (2013), 617-645.

[17] B. JESSEN, Bemaerkinger om konvekse Funktioner og Uligheder imellem Middelvaerdier I, Mat. Tidsskrift. B, (1931), 17-28. 
[18] T. KAILATH, The divergence and Bhattacharyya distance measures in signal selection, IEEE Transuctions Commun. Technol. 15, 1 (1967), 52-60.

[19] M. KRnIĆ, R. MiKIĆ AND J. PEČARIĆ, Strengthened converses of the Jensen and Edmundson-LahRibarič inequalities, Advances in Operator Theory 1, 1 (2016), 104-122.

[20] K. Krulić Himmelreich, J. PeČArić And D. PoKaZ, Inequalities of Hardy and Jensen / New Hardy type inequalities with general kernels, Monographs in inequalities 6, Element, Zagreb.

[21] J. Liang AND G. SHI, Comparison of differences among power means $Q_{r, \alpha}(a, b, \boldsymbol{x}) s$, J. Math. Inequal. 9, 2 (2015), 351-360.

[22] J. Lin AND S. K. M. Wong, Approximation of discrete probability distributions based on a new divergence measure, Congressus. Numerantiitm. 61, (1988), 75-80.

[23] B. Manaris, D. Vaughan, C. S. Wagner, J. Romero and R. B. Davis, Evolutionary Music and the Zipf-Mandelbrot Law: Developing Fitness Functions for Pleasant Music, Proceedings of 1st European Workshop on Evolutionary Music and Art (EvoMUSART2003) (2003), 522-534.

[24] D. Moulllot AND A. LePretre, Introduction of relative abundance distribution (RAD) indices, estimated from the rank-frequency diagrams (RFD), to assess changes in community diversity, Environmental Monitoring and Assessment, Springer 63, 2 (2000), 279-295.

[25] J. E. PeČarić, F. Proschan And Y. L. Tong, Convex functions, Partial orderings and statistical applications, Academic Press. Inc., San Diego.

[26] M. S ABABHEH, Improved Jensen's inequaliy, Math. Inequal. Appl. 20, 2 (2017), 389-403.

[27] Z. K. SilagadZe, Citations and the Zipf-Mandelbrot Law, Complex Systems 11, 6 (1997), 487-499. 